CREDIT Research Paper

No. 00/7

\title{
Aid and Growth Regressions
}

by

Henrik Hansen and Finn Tarp

Centre for Research in Economic Development and International Trade, University of Nottingham 
The Centre for Research in Economic Development and International Trade is based in the School of Economics at the University of Nottingham. It aims to promote research in all aspects of economic development and international trade on both a long term and a short term basis. To this end, CREDIT organises seminar series on Development Economics, acts as a point for collaborative research with other UK and overseas institutions and publishes research papers on topics central to its interests. A list of CREDIT Research Papers is given on the final page of this publication.

Authors who wish to submit a paper for publication should send their manuscript to the Editor of the CREDIT Research Papers, Professor M F Bleaney, at:

Centre for Research in Economic Development and International Trade,

School of Economics,

University of Nottingham,

University Park,

Nottingham, NG7 2RD,

UNITED KINGDOM

Telephone (0115) 9515620

Fax: (0115) 9514159

CREDIT Research Papers are distributed free of charge to members of the Centre. Enquiries concerning copies of individual Research Papers or CREDIT membership should be addressed to the CREDIT Secretary at the above address. 


\section{CREDIT Research Paper}

\section{CREDIT}

No. 00/7

\section{Aid and Growth Regressions}

by

Henrik Hansen and Finn Tarp

Centre for Research in Economic Development and International Trade, University of Nottingham 


\section{The Authors}

Finn Tarp is Associate Professor and Director of the Development Economics Research Group (DORG), University of Copenhagen, and an External Fellow of CREDIT. Henrik Hansen is a member of DERG. 


\title{
Aid and Growth Regressions
}

\author{
By
}

Henrik Hansen and Finn Tarp

\begin{abstract}
This paper examines the relationship between foreign aid and growth in real GDP per capita as it emerges from simple augmentations of popular cross-country growth specifications. It is shown that aid in all likelihood increases the growth rate, and this result is not conditional on 'good' policy. There are, however, decreasing returns to aid, and the estimated effectiveness of aid is highly sensitive to the choice of estimator and the set of control variables. When investment and human capital are controlled for, no positive effect of aid is found. Yet, aid continues to impact on growth via investment. We conclude by stressing the need for more theoretical work before this kind of cross-country regressions are used for policy purposes.
\end{abstract}

\section{Outline}

1. Introduction

2. Cross-country aid effectiveness studies

3. Endogeneity of aid and country specific effects

4. Aid, capital accumulation, and growth

5. Conclusion 


\title{
Aid and growth regressions
}

\author{
Henrik Hansen, Finn Tarp ${ }^{\dagger}$ \\ DERG, University of Copenhagen, Denmark
}

First revision: January 2000

Second revision: May 2000

\begin{abstract}
This paper examines the relationship between foreign aid and growth in real GDP per capita as it emerges from simple augmentations of popular cross-country growth specifications. It is shown that aid in all likelihood increases the growth rate, and this result is not conditional on 'good' policy. There are, however, decreasing returns to aid, and the estimated effectiveness of aid is highly sensitive to the choice of estimator and the set of control variables. When investment and human capital are controlled for, no positive effect of aid is found. Yet, aid continues to impact on growth via investment. We conclude by stressing the need for more theoretical work before this kind of cross-country regressions are used for policy purposes.
\end{abstract}

JEL classification: $\mathrm{O} 1 ; \mathrm{O} 2 ; \mathrm{O} 4 ; \mathrm{C} 23$

Key words: Aid impact; Economic growth; Investment; Generalized method of moments; Panel data

${ }^{*}$ Corresponding author. DERG, University of Copenhagen, Studiestræde 6, DK-1455 Copenhagen K, Denmark Tel.:+45-35324405, fax: +45-35323085; E-mail: Henrik.Hansen@econ.ku.dk

†E-mail: Finn.Tarp@econ.ku.dk 


\section{Introduction}

The past 30 years have witnessed the publication of a large number of studies on aid effectiveness. The methods employed to study the subject range from detailed case studies at the project level to regression analyses of the growth impact of aid in samples of almost a hundred countries. The micro and macro analyses have generally been perceived to yield different results; many successful projects leaving no lasting imprint on economy wide growth rates. We concentrate in this paper on the aid-growth relation at the macro level as it emerges from cross-country regressions based on large panel data sets.

We compare recent growth studies in which the relationship between aid and growth is modeled as non-linear. On the one side, Burnside and Dollar $(1997,2000)$ have found evidence of threshold effects by the introduction of an aid-policy interaction term in the growth regressions. In their model, aid contributes positively to growth, but only in good policy environments. On the other side, Hadjimichael et al. (1995), Durbarry et al. (1998), and Lensink and White (1999) have found positive, but decreasing marginal returns to aid flows, by the introduction of aid squared. None of the studies provide models that encompass the other. This is unfortunate. It is important to evaluate contesting regression specifications within a common framework. We therefore formulate such a general model where quadratic aid and policy terms appear alongside the aid-policy interaction. It appears that a reduction to the Burnside-Dollar specification is not supported by the data. This is important in view of the widespread attention paid to the BurnsideDollar results.

Concern about simultaneity bias in aid-growth regressions, caused by potential endogeneity of aid, is another common feature in recent studies. Surprisingly, they all find negligible bias. Due to the importance of this finding for the conclusions drawn about the impact of aid, we re-visit the endogeneity issue and offer an explanation for why others conclude that aid is exogenous. Standard regressions confirm earlier affirmations. However, there are strong signs of biased results once the model is enlarged to take account of country specific effects. We argue that such effects are important and proceed to estimate a fairly standard growth model using ordinary least squares as well as a generalized method of moments estimator that yield consistent estimates, also in the presence of both endogenous regressors and country specific effects. Compared to the other studies mentioned, we find very different (and positive) estimates of the impact of aid.

Turning to the question why aid increases growth, we include investment and human capital in the growth regression. The result is that, conditional on these variables, aid has no effect on growth. We interpret this finding as supportive of the view that aid affects growth via capital accumulation. An equation for gross domestic investment as a share of GDP is also estimated. By introducing aid squared we allow for level effects by which the fraction of aid that is actually invested can change with the aid dependency ratio. We find that in the majority of countries, there is a one-to-one relation between increased aid flows and increased investment. In sum, our results confirm that the aid-investmentgrowth link is important, and this is not conditional on good policy.

The remainder of the paper is organized as follows: In section 2 we compare the latest cross-country aid-growth regressions. In section 3 we give results for the model when 
endogeneity of aid and country specific effects are taken into account simultaneously. The model is respecified to include the main determinants of capital accumulation in section 4 , in which we also examine the impact of aid on investment. Section 5 concludes.

\section{Cross-country aid effectiveness studies}

Hansen and Tarp (2000) provide a survey of empirical analyses from the last 30 years that make use of cross-country regressions in assessing the effectiveness of foreign aid. From 131 such regressions, a reasonably consistent pattern emerges: (i) aid increases aggregate saving, although not by as much as the aid flow, (ii) aid increases investment, and (iii) aid has a positive effect on the growth rate whenever growth is driven by capital accumulation.

In the 1990s a new generation of aid effectiveness studies appeared focusing on the relations between aid, policies, and growth. Boone $(1994,1996)$ signaled the shift, showing that aid has no impact on investment or growth in standard neo-classical growth models. The result was substantiated by panel data regressions based on a sample of more than 90 countries covering twenty years. ${ }^{1}$

Boone's theoretical results have later been qualified. Obstfeld (1999) shows that within the class of growth models, considered by Boone, an increase in aid raises both consumption and investment as well as the growth rate provided the economy is initially below the steady state. Burnside and Dollar (1997) reach a similar conclusion by modifying the growth model to take account of subsistence consumption. ${ }^{2}$

Boone's empirical results have also been questioned. The studies by Hadjimichael et al. (1995),, Durbarry et al. (1998),, Lensink and White (1999), and Burnside and Dollar (2000) are all based on fairly standard cross-country growth relations, modified to analyse the effectiveness of aid by adding foreign aid as a fraction of GDP. These studies have a lot in common, including overlap in samples and estimation methods; and in contrast to Boone (1994), they all find a positive impact of aid on growth. The crux of this difference is that while Boone treats the aid-growth relation as linear it is modelled as non-linear in the four other studies. Nevertheless, the empirical formulation of the non-linear relation varies. Burnside and Dollar use an interaction term between aid and an index of economic policy. The three other studies include aid squared as regressor.

The theoretical arguments put forward to motivate the non-linear specifications of the aid-growth relation are ad hoc. Hadjimichael et al. refer to absorptive capacity constraints. Durbarry et al. discuss Dutch disease problems and capacity constraints, and Lensink and White consider inappropriate technology and institutional destruction caused by the aid inflow. These causal mechanisms can all be interpreted as ways in which economic policy impacts on aid effectiveness. Capacity constraints and institutional destruction are closely related to macroeconomic governance and Dutch disease

\footnotetext{
${ }^{1}$ The lack of empirical association between aid and growth was also remarked by Mosley, Hudson, and Horrell (1987, 1992). See Hansen and Tarp (2000) for a critical assessment of their results.

${ }^{2}$ A move towards endogenous growth models can be found in Lensink and White (1999). They analyse the effectiveness of aid in a model with productive public expenditure, as in Barro (1990).
} 
reflects poor management of the exchange rate and domestic fiscal and monetary policy.

Burnside and Dollar, on the other hand, focus explicitly on the impact of policy on aid effectiveness. They note that in a neoclassical growth model the impact of aid on growth will be greater when there are fewer policy distortions affecting the incentives of economic agents. Hence, they hypothesize that synergy effects among aid and policy are critically important. These effects may work either through increased productivity of capital or because a larger fraction of the aid flow is actually invested. While it is true that the marginal productivity of capital, and hence of invested aid, increases as distortions in the incentive system decrease, it is not obvious as suggested by Burnside and Dollar that the synergy effect carries over from marginal productivity to partial elasticities, i.e., to the rate of growth. If so, we would expect to find synergy effects between the investment ratio and policy. To our knowledge, this effect has not yet been introduced in cross-country growth regressions. The incentive, or rather fungibility, hypothesis relied on by Burnside and Dollar may be valid. Yet, such an association continues to lack a proper theoretical foundation and does not arise directly from the neoclassical model with subsistence consumption.

To put the ad hoc nature of the theoretical arguments into further perspective, it can also be shown, as noted by Hansen and Tarp (2000), that both squared aid and interaction terms may arise simply as the result of a second order approximation of a standard Solow growth model. Thus, the use of a non-linear aid-growth specification does not have be be justified with reference to for example policy distortions. It may simply reflect increased precision in the approximation of the functional form. In sum, the preferred formulation of the non-linearity is at this stage of theoretical understanding an empirical issue.

Statistical significance of the synergy effect between aid and policy, on the one hand, and decreasing marginal returns to aid, on the other, can - and should - be evaluated within the same regression model. This is done in Table 1 in which the average rate of growth in per capita GDP in 56 countries and five periods, covering the years 1974-1993, is regressed on several policy and institutional control variables and aid. Throughout aid is measured as official development assistance, ODA, relative to the World Bank Data on GDP.

As the study by Burnside and Dollar is at odds with the three other studies and since it is the most widely known among the four, we find it appropriate to formulate the initial regression model in accordance with the specification used in Burnside and Dollar (2000) adding aid squared and policy squared to the regressors, though. In this way, we are also sure that the discrepancies between the results in Table 1 and the Burnside and Dollar results are not caused by issues related to model specification.

Following Burnside and Dollar, the central indicators of macroeconomic policy are the budget surplus relative to GDP, inflation, and trade openness, measured by the indicator variable defined by Sachs and Warner (1995). The three policy variables are used to construct a policy index, given by

$$
\text { Policy }=1.28+6.85 \text { Budget surplus }-1.4 \text { Inflation }+2.16 \text { Openness } .
$$

In addition to the central economic policy variables a number of other political and institutional indicators which have appeared in empirical growth studies over the last decade, 
are included. Specifically, the state of the financial system is proxied by M2 relative to GDP while ethnolingustic fractionalization, assassinations, and a measure of institutional quality are included to capture political instability and government bureaucracy.

The final control variable, apart from regional and period dummies, is the logarithm of the initial level of per capita GDP. This regressor captures the conditional convergence effects, which have been found in almost all empirical growth studies in the 1990s. ${ }^{3}$

Turning to the aid regressors, our general model includes aid, aid squared, aid times policy, and policy squared. Together with the three variables in the policy index these four regressors form the aid-policy response surface in a second-order polynomial regression. Omission of any one of the four variables, a priori, indicates definite knowledge about the form of the response surface. ${ }^{4}$ We do not know of any theory yielding this kind of insight, and this is exactly why we wish to re-evaluate the specific regression equations relied on in other studies departing from a more general framework. However, as the proposed model is linear in the parameters it is simple to estimate using standard regression techniques. Thereby the importance of the individual terms in the response surface can be evaluated statistically.

A topic related to polynomial regressions, and non-linear regressions in general, is the interpretation of parameter estimates. In the models estimated by Hadjimichael et al. (1995), Durbarry et al. (1998), and Lensink and White (1999) the aid variables are included as uncentered regressors. As a result the estimated coefficient to the aid variable is a measure of the partial effect of aid on growth evaluated at no (zero) aid. This parameter estimate is of little interest. We have therefore chosen to center the aid variable around the sample mean, so the the estimated aid-coefficient is the marginal effect of aid on growth evaluated at the mean, 0.061. Throughout, we also report the marginal effect at the median, 0.028. We do this because the distribution of aid over countries and time is extremely skewed. Hence, in terms of country coverage the effectiveness of aid is of more interest at the median than at the mean.

A final technical issue before we present the results concerns the estimation method. Again, following Burnside and Dollar, we show results of instrumental variable estimations in which all regressors involving aid are treated as endogenous. We use, however, a slightly different set of instruments. The main change is that we include all the aid regressors lagged one period. This extension leads to vast improvements in efficiency measured by the reduced form $R^{2}$ for the endogenous regressors without leading to a rejection of the over-identifying restrictions. ${ }^{5}$ As such our set of instruments is preferable.

Turning to the results, regression (1.1) in Table 1 is the general model that encompasses the two contesting more specific formulations as special cases which can be obtained by parametric restrictions. Quite a few of the control variables are highly insignificant having $t$-values well below one. Yet, the results for the non-aid related variables are in accordance with the findings in Burnside and Dollar (2000). It is therefore a striking

\footnotetext{
${ }^{3}$ Detailed data definitions and sources are given in Appendix A.

${ }^{4}$ See eg. Draper and Smith (1981) for a discussion of polynomial regressions.

${ }^{5} \mathrm{As}$ a consequence of this choice of instruments we only include five periods in the panel regressions as opposed to six periods in Burnside and Dollar.
} 
insight that the estimation results for the aid variables in regression (1.1) indicate that the statistically preferred model includes aid squared but no interaction term. ${ }^{6}$ The model without interaction is reported as regression (1.2). Evaluated from (1.2) aid appears to be quite efficient. An increase of one percentage point in the aid/GDP ratio leads to an increase of a 0.25 percentage point in the growth rate when the effect is evaluated at the average level of aid/GDP. The positive marginal effect decreases quite fast, and the turning point for which the marginal effect of an increase in aid becomes negative is within the sample range. Nonetheless, the specific aim of this section is not to evaluate the effectiveness of aid, per se. Instead focus is on evaluating the regression specifications proposed in other studies. It is therefore also of interest to test whether the specification using aid squared is more robust than a specification including interaction between aid and policy.

A simple test of the model is to compare the full sample results in (1.2) with results based on the sample preferred by Burnside and Dollar. This is so, especially because Burnside and Dollar did not obtain a significant estimate of the aid policy interaction in the full sample because five outliers affected their results. Regression (1.3) reports the estimated parameters of the model with squared aid based on the sample in which the five observations are excluded. It appears that they have only negligible effects when the squared aid term is included in the model.

If aid and policy are correlated, insignificance of the interaction term may be caused by multicollinearity problems, whereby the squared terms capture the potential and much looked for significance of aid-policy interaction. One simple way to check this is to estimate the model without the squared aid and squared policy terms. This leads to the Burnside and Dollar specification in regression (1.4). Neither aid nor the interaction between aid and policy are significant in this reduction of the general model. This indicates that multicollinearity is not the cause of the insignificance. Finally, the last regression in Table 1 reports the results of a regression in which we exclude both aid squared and the five outliers identified as such by Burnside-Dollar. This leads to a marginally significant parameter estimate for the interaction term, showing that we are capable of obtaining the Burnside Dollar results, but only through a statistically invalid reduction of our general model and sample data.

Our ability to find results that are similar to those of Burnside and Dollar is interesting as we use different data for two of the variables in the regressions. First, we rely on World Bank data to compute levels of real GDP per capita. Burnside and Dollar use data from the Penn World Table. Second, while we use a standard measure of aid, Burnside and Dollar use a new measure of effective development assistance, EDA, (Chang et al., 1998) and deflate this by the unit-value of imports price index from the IFS. The resulting real aid figure is then measured relative to the Penn World Table data on GDP.

While the first difference in data does make a difference, as shown in Barro and Sala-i-Martin (1995, chapter 12), this is only minor. The latter difference is potentially substantial. We have therefore re-estimated the five models in Table 1 using the exact data set used by Burnside and Dollar (2000) (not reported). The change in data only

\footnotetext{
${ }^{6} \mathrm{~A}$ test of joint exclusion of policy squared and the aid policy interaction results in a $p$-value of 0.84 .
} 
lead to minor changes in the parameters and, more importantly, none of the conclusions change.

By way of conclusion, in Hansen and Tarp (2000) we argue against evaluations of aid effectiveness that are based on (lack of) statistical significance of aid variables in regressions that do not reflect established theoretical or empirical results. A minimum requirement must certainly be that we are able to explain why our models yield different results before we draw (wide ranging) conclusions. Seen in this perspective, and from the point of view of the empirical growth literature from the past decade, the main problem with the regressions in Burnside and Dollar (2000) and Table 1 is that the log of the initial level of income is never significant, even at 15 or 20 percent levels of significance, as the $t$-values are all below $1 .^{7}$ This means that it appears - for some reason - that there is no statistically significant conditional convergence among the 56 countries in the sample. This is at odds with a large literature. This does not imply, of course, that there is no convergence, just that it is not clear in the estimated model, and there may also be good reasons for not finding conditional convergence among the countries in the sample. However, we find that the reasons must be explored and explained before drawing policy conclusions. Based on our experience and understanding, we hypothesize that most of the models used so far in evaluating aid effectiveness lack proper treatment of the joint effect of endogeneity of the aid flows, unobserved country specific factors, and conditional convergence. In sum, the results in Burnside and Dollar and our Table 1 provide simple examples of regressions in which too much emphasis is placed on aid and too little on proper modeling. In the remainder of this paper we will attempt to quantify the effects of the above kinds of misspecification of the regression models.

\section{Endogeneity of aid and country specific effects}

Boone (1994, 1996), Hadjimichael et al. (1995), and Burnside and Dollar (2000) explicitly consider simultaneity bias due to endogeneity of aid. Boone and Burnside and Dollar briefly discuss the reasons for the possible endogeneity of aid in the growth regressions. The main reason is that it is difficult to perceive of aid as a lump-sum transfer, independent of the level of income. Empirically, a negative relation between aid and income per capita is well established. ${ }^{8}$

If aid depends on the level of income and if there is conditional convergence towards a steady state in per capita income, aid cannot be exogenous with respect to growth as traditionally assumed. At most, we may hope that aid is predetermined. ${ }^{9}$ In the typical cross-country growth regression, variables are averaged over a time period of, say, five years. In this case we must assume that aid allocation decisions are made with a planning

\footnotetext{
${ }^{7} \mathrm{~A} t$-value below one is interesting as it implies that the regressors are dropped from the equations even when the most gentle selection criteria such as the adjusted $R^{2}$ or the final prediction error are used for model selection.

${ }^{8}$ See among many others the panel data aid allocation studies by Trumbull and Wall (1994) and Alesina and Dollar (2000).

${ }^{9}$ Predetermined means that the allocation of aid may be influenced by random events in past growth rates but not by contemporaneous events.
} 
horizon of five to six years in order to uphold an assumption of pre-determinedness. This is not easy, so the endogeneity issue needs to be taken serious, and it is - in our view actually one of the most interesting issues brought up by Boone and Burnside and Dollar.

Both Lensink and White (1999), and Burnside and Dollar (2000) test for endogeneity of aid using Durbin-Wu-Hausman (DWH) tests. The test statistics reveal that ordinary least squares estimates do not deviate significantly from instrumental variable estimates in the growth regressions when the aid regressors are treated as endogenous variables. In the same vein, the DWH tests given in Table 1 do not reject the null hypothesis of equality of the OLS and the IV-estimates. But we do not conclude on this basis that aid is exogenous. Instead, we argue that both estimators are inconsistent, which implies that the test statistics are not tests of endogeneity of aid in the growth regressions.

The parameters in Lensink and White (1999), Burnside and Dollar (2000), and our Table 1 are estimated under the assumption that none of the exogenous variables are correlated with the error term in the model. Specifically, there can be no country specific effects apart from country specific variations in the regressors. The existence of such unmodelled/unobserved effects renders the IV-estimators inconsistent because the country specific effects are correlated with the initial level of income.

Moreover, any significant correlation between the policy variables and unobserved country specific effects would also lead to inconsistency of the IV-estimators since the policy indicators are used as instruments. Whether macroeconomic indicators are strictly exogenous or not has been discussed intensively in the growth literature. The studies by Easterly and Levine (1997) and Temple (1998) point to persistent correlations between macroeconomic policy indicators and country specific, cultural, and socioeconomic characteristics in developing countries. In addition, part of the literature analyzing the relationship between inequality and growth points out that some policy variables depend on the distribution of income. ${ }^{10}$ If the effect of income distribution on growth is part of the error term, some policy variables will be endogenous.

Taken together, all this indicates that most of the explanatory variables in the recent aid-growth regressions are, probably, endogenous. It is therefore important to use estimators that are consistent also in the presence of endogenous regressors and country specific effects.

The econometric approaches to deal with these issues in the context of panel data models have developed in several stages in the literature over the past decade. ${ }^{11}$ For reasons of clarity in the following discussion, we therefore briefly outline below the regression model, the estimation problems, and the generalized method of moments (GMM) estimator, we have chosen to use. It offers a robust solution to the problems of misspecification, since it yields consistent estimates under fairly general assumptions.

The growth regression for $N$ countries and $T$ time periods, where countries are indexed by $i$ and time by $t$, can be formulated as

$$
\Delta y_{i, t}=\gamma y_{i, t-1}+\sum_{j=1}^{k} \beta_{j} x_{j, i, t}+\alpha_{t}+u_{i, t} .
$$

\footnotetext{
${ }^{10}$ See e.g., Alesina and Rodrik (1994) and Persson and Tabellini (1994).

${ }^{11}$ See, for example, Mátyás and Sevestre (1996) or the survey by Ahn and Schmidt (1999).
} 
Here $\Delta y_{i, t}$ is the average growth rate, $y_{i, t-1}$ is the log of the initial level of per capita GDP, $x_{j, i, t}$ are the $k$ additional regressors, and $\alpha_{t}$ is a constant term that may change over time. The errors $u_{i, t}$ are decomposed into time invariant country specific effects, $\mu_{i}$, and random noise, $\varepsilon_{i, t}$ so

$$
u_{i, t}=\mu_{i}+\varepsilon_{i, t}
$$

This model formulation shows that the presence of country specific effects in the growth model $\left(\operatorname{var}\left(\mu_{i}\right)>0\right)$ leads to correlation between a regressor $\left(y_{i, t-1}\right)$ and the error term. This is the reason we argue that the IV-estimator used in Table 1 is inconsistent.

Static panel data models in which the regressors are correlated with the country specific effects are usually estimated using the so-called fixed effects (FE) estimator. The FE estimator requires, however, strict exogeneity of the explanatory variables with respect to the random error term, $\varepsilon_{i, t}$ because country specific time averages, $\bar{x}_{j, i, t}=\frac{1}{T} \sum x_{j, i, t}$ are used to transform the regressors and the dependent variable whereby the time averages of the random shocks, $\bar{\varepsilon}_{i, t}$, are introduced in the model. If some of the policy variables at time $t$ are correlated with the random shocks at some earlier time $s \leq t$, then the fixed effects estimator and instrumental variable estimators, based on the fixed effects transformation, are inconsistent. This is the case even if there is no conditional convergence.

In contrast, the instrumental variable estimator, introduced by Anderson and Hsiao (1981) for dynamic panels, yields consistent estimates of the parameters in (1). The solution lies in removing the country specific effects by differencing the data, whereby (1) becomes

$$
\begin{aligned}
& \Delta y_{i, t}-\Delta y_{i, t-1}= \\
& \quad \gamma\left(y_{i, t-1}-y_{i, t-2}\right)+\sum_{j=1}^{k^{\prime}} \beta_{j}\left(x_{j, i, t}-x_{j, i, t-1}\right)+\left(\alpha_{t}-\alpha_{t-1}\right)+\varepsilon_{i, t}-\varepsilon_{i, t-1} .
\end{aligned}
$$

In this model the regressors are clearly correlated with the error term under the above assumptions; $y_{i, t-1}$ is correlated with $\varepsilon_{i, t-1}$ and $x_{j, i, t}$ may be correlated with $\varepsilon_{i, t-1}$. This problem is solved by using lagged observations of the regressors as instruments. Specifically, under the assumption that $x_{j, i, t}$ is predetermined, $x_{j, i, t-1}$ is a valid instrument and $x_{j, i, t-2}$ is valid if $x_{j, i, t}$ is endogenous, as we assume for aid.

By noting that $x_{j, i, t-2}$ is also a valid instrument if $x_{j, i, t-1}$ is valid, it is clear that when the panel of countries is considered as a collection of cross-country regressions, the number of valid instruments in each cross-section is increasing in the time dimension. This property is utilized in various types of GMM estimators, and we have chosen to rely on the GMM estimator proposed by Arellano and Bond (1991). This estimator is linear and estimation software is freely available. ${ }^{12}$ Moreover, there is support in the crosscountry literature for this choice. In 1996, Caselli, Esquivel and Lefort advocated for the use of the GMM panel data estimator in an analysis of conditional convergence in the augmented Solow growth model, and more recently, Forbes (2000) has challenged established results about inequality and growth using the same estimator.

\footnotetext{
${ }^{12}$ All GMM results are obtained using the DPD package for OX, see Doornik, Arellano, and Bond (1999).
} 
In growth regressions there are two types of issues to consider when unobservered country specific effects are removed by differencing. They relate to loss of information and to the timing of relationships, say, from aid to growth. Brief comments on these issues are therefore in place.

Whether or not there is excessive loss of information when country means are removed depends on the subject matter and the data. The loss in data variation is certainly critical when for example the level of per capita GDP is compared across sub-Saharan Africa and OECD. However, this is not so when the growth rates of the 56 countries in the present sample are compared. ${ }^{13}$ In the upper part of Table 2 we report the mean, the standard deviation, and the correlation with the response variable (either growth or the changes in growth) for the central variables in the study. The first three columns are results for the levels of the variables, the last three are for the first-differences.

Taking a look at the standard deviations reported, Table 2 reveals that it is only when we consider the initial level of per capita GDP there is a major loss of variation. For the growth rate, there is little variation across countries as compared to across time, and for the central explanatory variables there is plenty of variation in the differences, i.e., over time. The variation in the differences may in principle be caused by purely random events, or measurement error. ${ }^{14}$ However, if this were the case, we should find a dramatic drop in the correlation between the explanatory variables and growth. As seen from Table 2 the correlations between the explanatory variables and growth is smaller for the differences compared to the levels, but still substantial.

The bottom part of Table 2 presents the same summary statistics as the upper part, but for a sub-sample of 45 countries, which in the following is used for comparisons. ${ }^{15}$ As can be seen, the differences between the two samples are minor for most of the variables.

An interesting result in Table 2 is the correlation between aid and growth. While the correlation is negative for the levels it is insignificant for the differences. Looking at the sub-sample of 45 countries the correlation even turns significantly positive for the differences. ${ }^{16}$ As we expect a non-linear relation between aid and growth, we cannot infer too much from the pairwise correlations in Table 2. This is, however, an example of divergent information in the cross-section dimension compared to the time-series dimension. Notice that having this result we may now argue in two ways: (i) high aid/GDP ratios are related to low growth, and (ii) increases in the aid/GDP ratio is related to increasing

\footnotetext{
${ }^{13}$ There are other issues when the purpose of the analysis is to estimate the speed of convergence, but this is not the objective of the present analysis.

${ }^{14}$ Consider for example a random variable $x_{t}$ with variance $\sigma^{2}$. If $x_{t}$ is uncorrelated over time, the variance in $x_{t}-x_{t-1}$ vill be $2 \sigma^{2}$.

${ }^{15}$ The selection of the smaller sample is based purely on data availability. The 45 countries are covered in the Nehru, Swanson, and Dubey (1995) database on human capital, which is further discussed in section 4. The regional distribution and the distribution of low- and middle-income countries is fairly constant in the two samples, although some of the extreme observations differ. There are differences with respect to the poorest, the richest, slowest-, and fastest-growing countries. There is also a change in the most aid dependent country.

${ }^{16}$ The only other variable for which there is a change in sign is the level of per capita income. Here the change is from a insignificant correlation to a significantly negative correlation. However this simply indicates that the income process is not stationary, whereas the growth process is.
} 
growth rates. Clearly, there is an identification problem, and this is exactly what we are discussing.

With respect to the issue of timing in the regressions using differences, this has been addressed by time-series econometricians. For macroeconomic data the so-called autoregressive distributed lags model, in which lags of the dependent variable as well as the explanatory variables are included in the regression, have proven to be quite useful. We have therefore experimented with lags of the growth rate and the explanatory variables in the regressions. This led to the introduction of the changes in aid, changes in aid squared, and the growth rate lagged one period. When these variables are introduced, the Budget surplus and Financial depth variables become highly insignificant. Consequently, they were left out.

Returning to the aid-growth results, we compare results from OLS- and GMM estimations, respectively. This will show that the choice of estimator matters a great deal and consequently, we must be cautious when the model is used for policy recommendations. We present in Table 3 the outcome of the reformulated growth regression. Regressions 3.1 and 3.3 in Table 3 are OLS regressions while 3.2 and 3.4 are GMM estimations. In regressions 3.2 and 3.4 we assume that changes in the policy variables are predetermined while there may be contemporaneous correlation between aid and the random shocks. The validity of the instruments is tested using Sargan's test for over-identifying restrictions and, as seen from the bottom of Table 3, the null hypothesis of valid instruments cannot be rejected. ${ }^{17}$

From Table 3 it is clear that 'aid effectiveness' is highly sensitive to the choice of estimator, while parameter estimates are reasonably constant across samples. The most striking result is the difference in the marginal effect of aid when the two estimators are compared. Using the OLS results for the large sample (3.1), an increase in the aid/GDP ratio of one percentage point - roughly from $6 \%$ to $7 \%$ - leads to an increase in the annual growth rate of 0.1 percentage point. Judging from the GMM results (3.2) the estimated effect is eight times higher, leading to an increase of almost one percentage point in the growth rate.

The effect of aid may seem excessively high in the GMM regressions as judged from the marginal effects alone. However, the strong transitory effect from changing aid-GDP ratios implies a much smaller reaction to aid inflows in the short run. The estimated immediate response in the growth rate to an increased aid flow is only about 0.2 percentage points. This is in accordance with the OLS results in Table 1 and 3, but the GMM results confirm that this is only the short run impact.

The main result we derive from Table 3 is the sensitivity of aid effectiveness conclusions to differences in estimation techniques and, hence, underlying assumptions. If country specific effects and endogeneity of the explanatory variables were of minor importance there should only be minor differences in the estimated parameters when comparing OLS and GMM results. This is not so. There is therefore empirical support for our initial hypothesis, and empirical assessments of the impact of aid on growth should be adjusted accordingly.

\footnotetext{
${ }^{17}$ Appendix B provides the details on the specification of the GMM regressions.
} 


\section{Aid, capital accumulation, and growth}

Even though the theoretical model underlying modern empirical aid-growth work has moved beyond the Harrod-Domar model, aid is still meant to impact on growth via capital accumulation. To analyze whether aid works through the investment link it is necessary to show that (i) investment impacts on growth, and (ii) aid impacts on investment. Accordingly, we reformulate the growth regression and include investment and human capital explicitly as shown in Table 4. If aid has an effect on growth, conditional on a fixed investment ratio and a constant level of human capital, then aid works through channels that impact on total factor productivity. ${ }^{18}$ To capture this, aid is retained as regressor.

One potential problem is to make sure that all sources of capital accumulation are included in the regressions. We therefore include gross domestic investment, foreign direct investment, and a measure of human capital. Even though these variables may not be exhaustive they do cover the main sources. In the regressions, we use the logarithm of gross domestic investment relative to GDP (gdi), while foreign direct investment (fdi) and aid, both as shares of GDP, were transformed as $\ln (1+x)$. The squares of the last two variables are also included.

The measure of human capital, mean years of education at the primary and secondary level, is from the Nehru et al. (1995) database. The data is available for 45 countries in our sample. However, the database only covers 1960-87. It was therefore necessary to generate country specific forecasts for the year 1990. This was done using exponential smoothing. The human capital variable enters the regressions untransformed in accordance with the findings in Benhabib and Spiegel (1994), and others.

The results in Table 4 are straightforward. Once we control for gross domestic investment, the only significant policy indicator is inflation. Again, the two estimation methods yield widely different results. In the OLS-regression (4.1) aid has a marginally positive effect, while there is no effect when judged from the GMM regression (4.2).

Adding foreign direct investment, as in regressions (4.3) and (4.4), does not change the effect of gross domestic investment, but it has a sizeable effect on the response to aid in the GMM regression. Foreign direct investment, by itself, has a considerable impact on growth. This is partly because fdi is very sensitive to the policy regime and the institutional quality in the host country, and partly because fdi is an important vehicle for technology transfers, see de Mello (1997) and Borensztein et al. (1998). Hence, in growth regressions foreign direct investment has a triple role; as a flash indicator of good institutions and good policy, by contributing to capital accumulation, and by increasing total factor productivity. In the GMM regressions we find high marginal effects of fdi but also strong non-linearities indicating rapidly decreasing returns. However, in more than $99 \%$ of the sample the fdi ratio is low enough to ensure a positive effect.

Adding human capital, as done in regressions (4.5) and (4.6), does not lead to sig-

\footnotetext{
${ }^{18}$ It has for example been argued that aid leads to investment in inappropriate technologies. If so there will be a negative effect of aid in a regression that includes investment. This effect may also be a result of institutional destruction.
} 
nificant changes in the OLS regression results where the human capital variable is highly insignificant. The result is quite different when we use GMM. In (4.6) human capital is significant and the inclusion leads to an increase in the responsiveness to changes in gross domestic investment while the response to foreign direct investment is unchanged.

In the present context the most interesting result is that once we condition on domestic investment in regression (4.2), aid has no impact on growth. In regression (4.6) where we also condition on human capital, the marginal effect of aid evaluated at the mean is even negative, while it is zero at the median. In the intermediate case in (4.4), in which we condition on only gdi and fdi, aid appears to have a positive effect on growth. ${ }^{19} \mathrm{We}$ interpret these results as indicating that aid may have had a negative marginal effect on total factor productivity for highly aid dependent countries. However, this effect has been dominated by the positive impact working through investment as shown below.

Table 5 presents investment regressions in which the policy variables from Table 3 are used as regressors alongside foreign direct investment, human capital, GDP per capita, and aid. The regressions may be seen as quasi-reduced form equations and, as such, they are similar to the relations presented in Barro (1998), Borensztein et al. (1998), and Feyzioglu et al. (1998). These studies also show the rather broad spectrum of possible (quasi-)reduced forms.

As for the growth specification, we present results for two different estimators. For investment the presence of country specific effects is evident as noted in Feyzioglu et al. (1998). We have therefore replaced the OLS regressions with fixed effects (FE) regressions, and in the GMM regressions we take account of potential correlations between the random shocks and aid, fdi, and the growth rate in GDP per capita, respectively. We use again both linear and squared terms of aid and fdi as regressors to capture level dependent crowding-in or -out.

If the explanatory variables are strictly exogenous there should be no significant difference between the FE and the GMM results. Yet, the two estimators do show different results. Gross domestic investment does not respond to foreign direct investment when judged by the FE regressions, but the GMM regressions show crowding-out effects. It is not possible to say a priori whether foreign direct investments substitute or complement domestic investment. Borensztein et al. (1998) find signs of threshold effects depending on the level of human capital. In our regressions, crowding-out effects related to fdi seem to be a general phenomenon in all countries. ${ }^{20}$

Human capital is also a substitute for domestic investment, as often found in other studies, and we find roughly the same parameter estimates in the two regressions. In addition, the response to openness, the growth rate in income, and the level of income seem fairly constant across the samples and estimation methods.

In all regressions in Table 5 we find a significant positive impact of aid on investment, as expected. Furthermore, there are strong transitory effects of aid. This leads to smaller

\footnotetext{
${ }^{19}$ Throughout, the effect of aid is insignificant in one-step GMM regressions.

${ }^{20}$ The turning points in the polynomials are at 0.054 and 0.045 for regressions (5.2) and (5.4), respectively. These fdi shares are above $99 \%$ of the sample values. We have estimated models with interaction effects between human capital and fdi as in Borensztein et al. The interaction term was not significant.
} 
responses to changes in the aid flow within the first four years. Yet, in the longer run the responses are quite large. From the FE results we find a response between 2/3 and $3 / 4$ at the median. In contrast, the response in the GMM regressions exceed unity at the median. ${ }^{21}$ Altogether, the evidence supports that aid is effective in increasing capital accumulation.

The investment and growth equations underlying the results in Table 4 and 5 make up a simultaneous system from which we conclude that aid is in general effective in furthering growth. ${ }^{22}$ There are, however, decreasing marginal returns to aid, captured through level effects from squared aid in the investment regression. There is also level dependence on investment in the reduced form of the growth relation due to the functional specification of the relationship between investment and growth. The aid-growth relationship therefore depends not only on the level of aid, but also on the levels of all the regressors in the investment function. They include key policy indicators.

There are, in other words, interaction effects at work between aid and policy in the system presented here. Yet, these effects impact through investment and are more intricate than the simple Burnside-Dollar aid-policy interaction. In any case, given that the interaction in our model depends on an ad hoc choice of logarithmic transformation of gross domestic investment relative to GDP (gdi), great care is required in drawing structural implications from this result.

\section{Conclusion}

Aid effectiveness is likely to remain a contentious area of debate. Substantial resources are involved, and the widespread perception that aid has been ineffective in fostering growth at the macro level has led to aid fatigue in many donor countries. In this paper we have investigated what modern cross-country growth regressions can tell about the effect of aid on aggregate growth. We find that aid increases the growth rate, and this conclusion is not conditional on the policy index proposed by Burnside and Dollar (2000).

Using a fairly standard growth model capturing non-linear effects between aid and growth, the empirical specification, with most support by data, does not include an aidpolicy interaction term. We therefore believe to have substantiated that it is premature to rely on simple policy indexes such as the one proposed by Burnside-Dollar. It provides a tunnel vision that may not prove beneficial when grappling with the complexities of the role and impact of aid.

We also note that empirical conclusions about aid effectiveness that are based on cross-country growth regressions depend on poorly understood non-linearities and critical methodological choices. As such, lack of robustness should not really come as a surprise. On this background, it might be tempting to discard cross-country growth regressions altogether. We do not opt for this alternative, however. Some regularities do

\footnotetext{
${ }^{21}$ Levy (1987) and Feyzioglu et al. (1998) also find signs of crowding-in, although they do not consider a level dependence in the response.

${ }^{22}$ It is beyond the scope of the present paper to estimate jointly the two equations. Moreover, as we model most of the explanatory variables as endogenous we should ideally present a non-linear system with five or six equations.
} 
seem to exist across countries. The focus in this paper has been on whether there is regularity in the impact of aid across countries. This seems to be the case.

The diversity of developing countries in their natural endowments and cultural and socioeconomic characteristics is another recurrent theme in cross-country comparisons of aid effectiveness. In this paper the effect hereof on the growth impact of aid is captured through the introduction of country specific effects in the regressions. Moreover, aid allocation issues are taken into account by inclusion of aid as an endogenous regressor. It emerges that these two factors have strong implications for the empirical results.

Finally, we reconfirm the empirical support for the hypothesis that aid impacts on growth via investment. This effect is shown to be potent, while an alleged negative effect on total factor productivity has only weak support in the data. In this context, we also find potentially important interaction effects between aid and some central policy variables. This finding should, however, as just pointed out be interpreted with caution.

The above observations underline that it is at this stage doubtful to rely on crosscountry regression results such as those discussed in this paper in formulating policy recommendations. Better theoretical explanations about the aid-investment-growth processes are required before we can derive satisfactory empirical specifications and formulate useful testable hypotheses.

\section{A. Data appendix}

\begin{tabular}{|c|c|c|}
\hline Variable name & Description & Source \\
\hline Aid & Official development assistance as a share of GDP & OECD-DAC (1998) \\
\hline Assassinations & Number of assissanations per 100,000 population & Easterly and Levine (1997) \\
\hline Budget surplus & Budget surplus (share of GDP & Burnside and Dollar (2000) \\
\hline Ethnic fract. & Index of ethnolinguistic fractionalization, 1960 & Easterly and Levine (1997) \\
\hline Fdi & Foreign direct investment (share of GDP) & WDI (1997) \\
\hline Financial depth & M2 (share of GDP), lagged one period & Burnside and Dollar (2000) \\
\hline Gdi & Gross domestic investment (share of GDP) & WDI (1997) \\
\hline GDP & $\begin{array}{l}\text { Growth rate and initial level of real per capita } \\
\text { GDP }\end{array}$ & WDI (1997) \\
\hline Gov. consumption & General government consumption (share of GDP) & WDI (1997) \\
\hline Human capital & $\begin{array}{l}\text { Mean school years of education at the primary } \\
\text { and secondary level }\end{array}$ & Nehru et al. (1995) \\
\hline Inflation & Log differences of CPI & Burnside and Dollar (2000) \\
\hline Inst. quality & $\begin{array}{l}\text { Institutional quality; security of property rights } \\
\text { and efficiency of the government bureaucracy }\end{array}$ & Knack and Keefer (1995) \\
\hline Openness & Indicator variable for trade openness & Sachs and Warner (1995) \\
\hline Policy & $\begin{array}{l}\text { Index of economic policy. Policy }=1.28+6.85 \\
\text { Budget surplus }-1.4 \text { Inflation }+2.16 \text { Openness }\end{array}$ & Burnside and Dollar (2000) \\
\hline
\end{tabular}


Countries in the sample

Countries with an asterisk are not included in the 45 country sample.

\begin{tabular}{llll}
\hline Algeria & Ethiopia & Malawi & Somalia* \\
Argentina & Gabon* & Malaysia & Sri Lanka \\
Bolivia & Gambia, The* & Mali & Syrian Arab Rep.* \\
Botswana* & Ghana & Mexico & Tanzania \\
Brazil & Guatemala & Morocco & Thailand \\
Cameroon & Guyana* & Nicaragua* & Togo* \\
Chile & Haiti & Niger* & Trinidad and Tobago* \\
Colombia & Honduras & Nigeria & Tunisia \\
Costa Rica & India & Pakistan & Turkey \\
Cote d'Ivoire & Indonesia & Paraguay & Uruguay \\
Dominican Republic** & Jamaica & Peru & Venezuela \\
Ecuador & Kenya & Philippines & Zaire \\
Egypt, Arab Rep. & Korea, Rep. & Senegal & Zambia \\
El Salvador & Madagascar & Sierra Leone & Zimbabwe \\
\hline
\end{tabular}

\section{B. Instruments in the regressions in Tables 3 - 5}

$\mathrm{D}(k)$ indicates that the first-differences of the variable, lagged $k$ periods, is used as instrument while $\mathrm{G}\left(k_{1}, k_{2}\right)$ implies that the variable, lagged at least $k_{1}$ periods and including up to $k_{2}$ lags when possible, is used as instrument. The human capital variable is only used as instrument in the regressions in which the variable is included as regressor.

\begin{tabular}{lccc}
\hline Variable & 3 & 4 & Table \\
\hline Growth rate in GDP per capita & $\mathrm{G}(2,3)$ & $\mathrm{G}(2,3)$ & $\mathrm{G}(2,3)$ \\
Aid & $\mathrm{G}(2,3)$ & & $\mathrm{G}(2,3)$ \\
Aid $^{2}$ & $\mathrm{G}(2,3)$ & & $\mathrm{G}(2,2)$ \\
Inflation & $\mathrm{G}(1,2)$ & $\mathrm{G}(1,2)$ & $\mathrm{G}(1,2)$ \\
Openness & $\mathrm{D}(0)$ & & $\mathrm{D}(0)$ \\
Assassinations & $\mathrm{D}(0)$ & & \\
Ethnic. $\times$ Assassinations & $\mathrm{D}(0)$ & & \\
$\ln (1+$ aid) & & $\mathrm{G}(2,3)$ & \\
$\ln (1+$ aid) & & $\mathrm{G}(2,3)$ & \\
$\ln ($ gdi) & & $\mathrm{G}(2,3)$ & \\
$\ln (1+$ fdi) & & $\mathrm{G}(2,3)$ & $\mathrm{G}(2,3)$ \\
Gdi & & $\mathrm{G}(2,3)$ & $\mathrm{G}(2,3)$ \\
Fdi & & $\mathrm{G}(2,3)$ & $\mathrm{G}(2,2)$ \\
Fdi & & $\mathrm{G}(1,2)$ \\
$\ln ($ initial GDP per capita) & $\mathrm{G}(1,2)$ & $\mathrm{G}(1,2)$ & $\mathrm{G}(1,3)$ \\
Gov. consumption & $\mathrm{G}(1,3)$ & $\mathrm{G}(1,3)$ & $\mathrm{G}(1,2)$ \\
Financial depth & & $\mathrm{G}(1,2)$ & $\mathrm{D}(1), \mathrm{G}(1,1)$ \\
Human capital & & $\mathrm{D}(1), \mathrm{G}(1,1)$ & \\
\hline
\end{tabular}




\section{References}

Ahn, S. C. and P. Schmidt (1999). Estimation of linear panel data models using GMM. In L. Mátyás (Ed.), Generalized Method of Moments Estimation, Chapter 8, pp. 211-247. Cambridge, UK: Cambridge University Press.

Alesina, A. and D. Dollar (2000). Who gives foreign aid to whom and why? Journal of Economic Growth 5,33-63.

Alesina, A. and D. Rodrik (1994). Distributive politics and economic growth. Quarterly Journal of Economics 108, 465-490.

Anderson, T. W. and C. Hsiao (1981). Estimation of dynamic models with error components. Journal of the American Statistical Association 76, 598-606.

Arellano, M. and S. Bond (1991). Some tests of specification for panel data: Monte Carlo evidence and an application to employment equations. Review of Economic Studies 58, 277-297.

Barro, R. J. and X. Sala-I-Martin (1995). Economic Growth. McGraw-Hill, Inc.

Barro, R. J. (1990). Government spending in a simple model of endogenous growth. Journal of Political Economy 95(5), S103-125.

Barro, R. J. (1998, October). Human capital and growth in cross-country regressions. Harvard University, processed.

Benhabib and M. M. Spiegel (1994). The role of human capital in economic development. Evidence from aggregate cross-country data. Journal of Monetary Economics 34, 143-173.

Boone, P. (1994). The impact of foreign aid on savings and growth. Mimeo, London School of Economics.

Boone, P. (1996). Politics and the effectiveness of foreign aid. European Economic Review 40, 289-329.

Borensztein, E., J. De Gregio, and J.-W. Lee (1998). How does foreign direct investment affect economic growth? Journal of International Economics 45, 115-135.

Burnside, C. and D. Dollar (1997). Aid, policies and growth. Policy Research Working Paper 1777, The World Bank, Development Research Group, Washington, D. C.

Burnside, C. and D. Dollar (2000). Aid, policies, and growth. American Economic Review. Forthcoming.

Chang, C. C., E. Fernandez-Arias, and L. Servén (1998). Measuring aid flows: A new approach. Working paper, The World Bank. Processed.

de Mello, L. R. (1997). Foreign direct investment in developing cointries and growth: A selective survey. Journal of Development Studies 34(1), 1-34.

Doornik, J. A., M. Arellano, and S. Bond (1999). Dynamic panel data estimation using DPD for Ox. Processed.

Draper, N. R. and H. Smith (1981). Applied Regression Analysis (Second ed.). New York: John Wily \& Sons.

Durbarry, R., N. Gemmell, and D. Greenaway (1998). New evidence on the impact of foreign aid on economic growth. CREDIT Research Paper 98/8, University of Nottingham.

Easterly, W. and R. Levine (1997). Africa's growth tragedy: Politics and ethnic divisions. Quarterly Journal of Economics 112, 1203-1250.

Feyzioglu, T., V. Swaroop, and M. Zhu (1998). A panel data analysis of the fungibility of foreign aid. The World Bank Economic Review 12(1), 29-58. 
Forbes, K. J. (2000). A reassessment of the relationship between inequality and growth. American Economic Review, Forthcoming.

Hadjimichael, M. T., D. Ghura, M. Mühleisen, R. Nord, and E. M. Uçer (1995). Sub-Saharan Africa: Growth, savings, and investment, 1986-93. Occasional Paper 118, International Monetary Fund.

Hansen, H. and F. Tarp (2000). Aid effectiveness disputed. Journal of International Development 12, 375-398.

Knack, S. and P. Keefer (1995). Institutions and economic performance: Cross-country tests using alternative institutional measures. Economics and Politics 7(3), 207-227.

Lensink, R. and H. White (1999). Is there an aid laffer curve? CREDIT Research Paper 99/6, University of Nottingham.

Levy, V. (1987). Does concessionary aid lead to higher investment rates in low-income countries? Review of Economics and Statistics LXIX, 152-156.

Mátyás, L. and P. Sevestre (1996). The Econometrics of Panel Data: Handbook of Theory and Applications (Second ed.). Dordrecht: Kluwer Academic Publishers.

Mosley, P., J. Hudson, and S. Horrell (1987). Aid, the public sector and the market in less developed countries. Economic Journal 97, 616-641.

Mosley, P., J. Hudson, and S. Horrell (1992). Aid, the public sector and the market in less developed countries : A return to the scene of the crime. Journal of International Development 4(2), $139-150$.

Nehru, V., E. Swanson, and A. Dubey (1995). A new database on human capital stock in developing and industrial countries: Sources, methodology, and results. Journal of Development Economics 46, 379-401.

Obstfeld, M. (1999). Foreign resource inflows, saving, and growth. In K. Schmidt-Hebbel and L. Servén (Eds.), The Economics of Saving and Growth, Chapter 5, pp. 107-146. Cambridge, UK: Cambridge University Press.

Persson, T. and G. Tabellini (1994). Is inequality harmful for growth? American Economic Review 84, 600-621.

Sachs, J. D. and A. M. Warner (1995). Economic reform and the process of global integration. Brooking Papers on Economic Activity 1, 1-118.

Temple, J. (1998). Initial conditions, social capital and growth in Africa. Journal of African Economies 7, 309-347.

Trumbull, W. and H. Wall (1994). Estimating aid-allocation criteria with panel data. Economic Journal 104, 876-882. 
Table 1

Growth regressions with polynomial effects of aid and policy

\begin{tabular}{|c|c|c|c|c|c|}
\hline \multirow{3}{*}{$\begin{array}{l}\text { Dependent variable } \\
\text { Sample } \\
\text { Regression }\end{array}$} & \multicolumn{5}{|c|}{ Annual growth rate in GDP per capita } \\
\hline & \multicolumn{5}{|c|}{56 countries, 5 periods ( $1974-77$ to $1990-93$ ) } \\
\hline & 1.1 & 1.2 & 1.3 & 1.4 & 1.5 \\
\hline Aid & 0.229 & 0.230 & 0.266 & 0.041 & 0.131 \\
\hline & $(2.18)$ & $(2.24)$ & (2.54) & (1.07) & $(2.65)$ \\
\hline $\mathrm{Aid}^{2}$ & $\begin{array}{c}-0.729 \\
(2.19)\end{array}$ & $\begin{array}{r}-0.737 \\
(2.25)\end{array}$ & $\begin{array}{r}-0.661 \\
(2.26)\end{array}$ & & \\
\hline Aid x Policy & $\begin{array}{c}-0.012 \\
(0.45)\end{array}$ & & & $\begin{array}{c}-0.012 \\
(0.48)\end{array}$ & $\begin{array}{c}0.085 \\
(1.74)\end{array}$ \\
\hline Policy $^{2}$ & $\begin{array}{l}0.0002 \\
(0.23)\end{array}$ & & & & \\
\hline Budget surplus & $\begin{array}{c}0.098 \\
(2.39)\end{array}$ & $\begin{array}{r}0.090 \\
(2.44)\end{array}$ & $\begin{array}{c}0.103 \\
(2.54)\end{array}$ & $\begin{array}{r}0.081 \\
(1.96)\end{array}$ & $\begin{array}{r}0.083 \\
(1.98)\end{array}$ \\
\hline Inflation & $\begin{array}{c}-0.012 \\
(2.24)\end{array}$ & $\begin{array}{r}-0.011 \\
(2.33)\end{array}$ & $\begin{array}{c}-0.008 \\
(1.51)\end{array}$ & $\begin{array}{r}-0.013 \\
(2.83)\end{array}$ & $\begin{array}{c}-0.014 \\
(2.35)\end{array}$ \\
\hline Openness & $\begin{array}{c}0.016 \\
(2.68)\end{array}$ & $\begin{array}{l}0.017 \\
(3.4)\end{array}$ & $\begin{array}{c}0.018 \\
(3.58)\end{array}$ & $\begin{array}{c}0.019 \\
(3.64)\end{array}$ & $\begin{array}{r}0.025 \\
(4.84)\end{array}$ \\
\hline Financial depth & $\begin{array}{c}0.010 \\
(0.57)\end{array}$ & $\begin{array}{c}0.011 \\
(0.58)\end{array}$ & $\begin{array}{c}0.010 \\
(0.52)\end{array}$ & $\begin{array}{c}0.019 \\
(1.14)\end{array}$ & $\begin{array}{c}0.017 \\
(0.97)\end{array}$ \\
\hline Ethnic fract. & $\begin{array}{l}0.002 \\
(0.2)\end{array}$ & $\begin{array}{l}0.0007 \\
(0.08)\end{array}$ & $\begin{array}{c}0.003 \\
(0.33)\end{array}$ & $\begin{array}{c}-0.001 \\
(0.16)\end{array}$ & $\begin{array}{c}-0.0008 \\
(0.09)\end{array}$ \\
\hline Assassinations & $\begin{array}{r}-0.453 \\
(1.98)\end{array}$ & $\begin{array}{c}-0.46 \\
(2.02)\end{array}$ & $\begin{array}{c}-0.483 \\
(2.15)\end{array}$ & $\begin{array}{r}-0.417 \\
(1.85)\end{array}$ & $\begin{array}{c}-0.428 \\
(1.89)\end{array}$ \\
\hline Ethnic x Assas. & $\begin{array}{c}0.908 \\
(2.14)\end{array}$ & $\begin{array}{c}0.916 \\
(2.16)\end{array}$ & $\begin{array}{c}0.952 \\
(2.28)\end{array}$ & $\begin{array}{c}0.776 \\
(1.89)\end{array}$ & $\begin{array}{r}0.789 \\
(1.89)\end{array}$ \\
\hline Inst. quality & $\begin{array}{c}0.804 \\
(4.51)\end{array}$ & $\begin{array}{r}0.804 \\
(4.54)\end{array}$ & $\begin{array}{c}0.818 \\
(4.56)\end{array}$ & $\begin{array}{r}0.673 \\
(4.22)\end{array}$ & $\begin{array}{c}0.756 \\
(4.58)\end{array}$ \\
\hline Initial GDP per capita & $\begin{array}{r}0.001 \\
(0.11)\end{array}$ & $\begin{array}{c}0.001 \\
(0.11)\end{array}$ & $\begin{array}{c}0.002 \\
(0.24)\end{array}$ & $\begin{array}{r}-0.002 \\
(0.35)\end{array}$ & $\begin{array}{r}-0.001 \\
(0.17)\end{array}$ \\
\hline Effect of aid at median & $\begin{array}{c}0.28 \\
(2.21)\end{array}$ & $\begin{array}{r}0.279 \\
(2.27)\end{array}$ & $\begin{array}{c}0.309 \\
(2.51)\end{array}$ & $\begin{array}{c}0.044 \\
(1.17)\end{array}$ & $\begin{array}{c}0.11 \\
(2.38)\end{array}$ \\
\hline Degrees of freedom & 211 & 213 & 208 & 213 & 208 \\
\hline DWH test ${ }^{a}$ & 0.26 & 0.14 & 0.06 & 0.31 & 0.14 \\
\hline Sargan test ${ }^{b}$ & 0.24 & 0.38 & 0.64 & 0.05 & 0.28 \\
\hline$\hat{\sigma}_{\varepsilon} \times 100$ & 3.0 & 2.98 & 2.99 & 2.97 & 2.95 \\
\hline
\end{tabular}

${ }^{a}$ The $p$-value of the Durbin-Wu-Hausman test for equality of the OLS and the IV estimates. ${ }^{b}$ The $p$-value of Sagan's test for overidentifying restrictions. Heteroskedasticity-consistent $t$-values in parenthesis. Time dummies and dummies for Sub-Saharan Africa and East Asia are included in all regressions. Regressions 1.3 and 1.5 exclude five observations as discussed in the main text. The five observations are: Nicaragua (1986-89, 1990-93), Gambia (1986-89, 1990-93) and Guyana (1990-93). Instruments: Infant mortality, Arms imports $(t-1)$, Dummy for Egypt, Policy $(t-1)$, Policy $^{2}(t, t-1)$, Policy $\times \ln$ (population), Policy $\times$ infant mortality, Policy $\times$ aid $(t-1)$, Policy $\times \operatorname{aid}^{2}(t-1)$, aid $(t-1), \operatorname{aid}^{2}(t-1)$. The reduced form $R^{2}$ measures for the endogenous regressors, Aid, $\mathrm{Aid}^{2}$ and Aid $\times$ policy, are 0.84, 0.68, and 0.67, respectively. 
Table 2

Summary statistics for the central variables in the analysis

\begin{tabular}{|c|c|c|c|c|c|c|}
\hline \multirow[b]{3}{*}{ Variable } & \multicolumn{6}{|c|}{56 countries } \\
\hline & \multicolumn{3}{|c|}{$\begin{array}{l}\text { Series in levels } \\
268 \text { observations }\end{array}$} & \multicolumn{3}{|c|}{$\begin{array}{l}\text { Series in differences } \\
263 \text { observations }\end{array}$} \\
\hline & Mean & Std.dev. & Corr. $^{a}$ & Mean & Std.dev & Corr. $^{a}$ \\
\hline Growth rate in per capita GDP & 0.0086 & 0.0359 & & -0.0045 & 0.0423 & \\
\hline Aid & 0.0581 & 0.0822 & -0.14 & 0.0112 & 0.0404 & 0.06 \\
\hline Inflation & 0.2538 & 0.3989 & -0.22 & 0.0458 & 0.3083 & -0.15 \\
\hline Openness & 0.2575 & 0.4116 & 0.34 & 0.0865 & 0.2628 & 0.20 \\
\hline Gdi & 0.2215 & 0.0765 & 0.48 & 0.0013 & 0.0510 & 0.40 \\
\hline Fdi & 0.0084 & 0.0130 & 0.31 & 0.0004 & 0.0158 & 0.26 \\
\hline \multirow[t]{3}{*}{$\log ($ initial per capita GDP) } & 6.6396 & 0.8829 & 0.10 & 0.0405 & 0.1420 & -0.21 \\
\hline & \multicolumn{6}{|c|}{45 countries } \\
\hline & \multicolumn{3}{|c|}{$\begin{array}{l}\text { Series in levels } \\
214 \text { observations }\end{array}$} & \multicolumn{3}{|c|}{$\begin{array}{c}\text { Series in differences } \\
210 \text { observations }\end{array}$} \\
\hline Variable & Mean & Std.dev. & Corr. $^{a}$ & Mean & Std.dev & Corr. $^{a}$ \\
\hline Growth rate in per capita GDP & 0.0095 & 0.0324 & & -0.0044 & 0.0368 & \\
\hline Aid & 0.0436 & 0.0579 & -0.16 & 0.0084 & 0.0282 & 0.12 \\
\hline Inflation & 0.2610 & 0.3693 & -0.21 & 0.0467 & 0.2715 & -0.19 \\
\hline Openness & 0.2839 & 0.4241 & 0.38 & 0.0905 & 0.2770 & 0.23 \\
\hline Gdi & 0.2141 & 0.0707 & 0.49 & 0.0016 & 0.0487 & 0.31 \\
\hline Fdi & 0.0075 & 0.0100 & 0.28 & 0.0008 & 0.0112 & 0.29 \\
\hline $\log ($ initial per capita GDP) & 6.6261 & 0.8362 & 0.12 & 0.0463 & 0.1314 & -0.28 \\
\hline
\end{tabular}

${ }^{a}$ Corr. is the correlation between the dependent variable, the growth rate, and the explanatory variable. In the columns with differences both variables are differenced. 
Table 3

Growth regressions with country specific effects

\begin{tabular}{|c|c|c|c|c|}
\hline \multirow{4}{*}{$\begin{array}{l}\text { Dependent variable } \\
\text { Sample } \\
\text { Estimation method } \\
\text { Regression }\end{array}$} & \multicolumn{4}{|c|}{ Annual growth rate in GDP per capita } \\
\hline & \multicolumn{2}{|c|}{56 countries } & \multicolumn{2}{|c|}{45 countries } \\
\hline & $\overline{\text { OLS }}$ & GMM & OLS & GMM \\
\hline & 3.1 & 3.2 & 3.3 & 3.4 \\
\hline \multirow[t]{2}{*}{ Aid } & 0.117 & 0.905 & 0.090 & 0.559 \\
\hline & $(2.00)$ & $(4.22)$ & $(1.49)$ & $(1.77)^{\dagger}$ \\
\hline \multirow[t]{2}{*}{$\mathrm{Aid}^{2}$} & -0.301 & -2.012 & 0.04 & -4.304 \\
\hline & $(1.97)$ & $(3.83)$ & $(0.07)$ & $(2.56)$ \\
\hline \multirow[t]{2}{*}{$\Delta$ Aid } & -.198 & -0.697 & -.184 & -0.563 \\
\hline & $(1.69)$ & $(4.91)$ & $(1.33)$ & $(2.96)$ \\
\hline \multirow[t]{2}{*}{$\Delta \mathrm{Aid}^{2}$} & 0.380 & 0.981 & 0.112 & 4.537 \\
\hline & $(1.32)$ & (3.64) & $(0.14)$ & $(2.24)$ \\
\hline \multirow[t]{2}{*}{ Inflation } & -0.012 & -0.002 & -0.010 & -0.000 \\
\hline & $(4.00)$ & $(0.30)$ & $(3.10)$ & $(0.00)$ \\
\hline \multirow[t]{2}{*}{ Openness } & 0.022 & 0.028 & 0.018 & 0.016 \\
\hline & $(4.50)$ & $(4.37)$ & $(3.59)$ & $(2.49)$ \\
\hline \multirow[t]{2}{*}{ Assassinations } & -0.331 & $-0.534^{\dagger}$ & -0.239 & $-0.44^{\dagger}$ \\
\hline & $(1.44)$ & $(2.31)$ & $(0.99)$ & $(1.93)$ \\
\hline \multirow[t]{2}{*}{ Ethnic x Assassinations } & 0.590 & 1.004 & 0.398 & $0.804^{\dagger}$ \\
\hline & $(1.46)$ & $(2.75)$ & $(0.96)$ & $(2.25)$ \\
\hline \multirow[t]{2}{*}{ Lagged growth rate } & 0.082 & -0.369 & 0.106 & -0.466 \\
\hline & $(1.16)$ & $(7.09)$ & $(1.45)$ & $(4.49)$ \\
\hline \multirow[t]{2}{*}{$\ln$ (initial GDP per capita) } & -0.003 & -0.036 & -0.005 & $-0.062^{\dagger}$ \\
\hline & $(0.61)$ & $(1.05)$ & $(1.90)$ & $(1.74)$ \\
\hline \multirow[t]{2}{*}{ Effect of aid at median } & 0.137 & 1.038 & 0.088 & 0.843 \\
\hline & $(2.03)$ & $(4.21)$ & (1.05) & $(2.13)$ \\
\hline Degrees of freedom & 251 & 199 & 197 & 156 \\
\hline$\hat{\sigma}_{\varepsilon} \times 100$ & 2.90 & 2.53 & 2.52 & 2.3 \\
\hline Sargan test ${ }^{a}$ & & 0.39 & & 0.46 \\
\hline
\end{tabular}

${ }^{\dagger}$ The parameter is not significant at the $10 \%$ level in a one-step GMM estimation.

${ }^{a}$ The $p$-value of Sargan's test for overidentifying restrictions. Heteroskedasticityconsistent $t$-values in parenthesis. Time dummies are included in all regressions. Institutional quality and dummies for Sub-Saharan Africa and East Asia are included in the OLS regressions. 
Table 4

Growth regressions with investment and human capital

\begin{tabular}{|c|c|c|c|c|c|c|}
\hline \multirow{3}{*}{$\begin{array}{l}\text { Dependent variable } \\
\text { Sample } \\
\text { Estimation method }\end{array}$} & \multicolumn{6}{|c|}{ Annual growth rate in GDP per capita } \\
\hline & \multicolumn{4}{|c|}{56 countries } & \multicolumn{2}{|c|}{45 countries } \\
\hline & OLS & GMM & OLS & GMM & OLS & GMM \\
\hline Regression & 4.1 & 4.2 & 4.3 & 4.4 & 4.5 & 4.6 \\
\hline \multirow[t]{2}{*}{$\ln (1+$ aid $)$} & 0.108 & 0.077 & 0.078 & $0.251^{\dagger}$ & 0.083 & $-0.142^{\dagger}$ \\
\hline & $(1.74)$ & $(0.40)$ & (1.33) & $(2.31)$ & (1.32) & (2.11) \\
\hline \multirow[t]{2}{*}{$\ln (1+\text { aid })^{2}$} & -0.542 & -0.414 & -0.422 & $-0.931^{\dagger}$ & -0.114 & $-1.366^{\dagger}$ \\
\hline & $(2.53)$ & $(0.64)$ & $(2.12)$ & (2.68) & $(0.18)$ & $(1.56)$ \\
\hline \multirow[t]{2}{*}{$\Delta \ln (1+$ aid $)$} & -0.228 & $-0.683^{\dagger}$ & -0.184 & -0.164 & -0.194 & $-0.607^{\dagger}$ \\
\hline & $(1.87)$ & (3.77) & $(1.56)$ & $(1.51)$ & (1.37) & (2.62) \\
\hline \multirow[t]{2}{*}{$\Delta \ln (1+\text { aid })^{2}$} & 0.539 & $1.041^{\dagger}$ & 0.415 & 0.200 & -0.076 & $3.337^{\dagger}$ \\
\hline & $(1.5)$ & $(3.65)$ & (1.19) & $(0.88)$ & $(0.08)$ & $(2.44)$ \\
\hline \multirow[t]{2}{*}{ Inflation } & -0.009 & -0.001 & -0.008 & $-0.015^{\dagger}$ & -0.005 & $-0.024^{\dagger}$ \\
\hline & $(2.16)$ & $(0.21)$ & $(1.88)$ & (4.53) & $(1.50)$ & $(2.60)$ \\
\hline \multirow[t]{2}{*}{ Lagged growth rate } & -0.002 & -0.351 & -0.002 & -0.295 & 0.004 & -0.356 \\
\hline & $(0.02)$ & $(6.76)$ & $(0.03)$ & $(10.6)$ & $(0.06)$ & $(8.77)$ \\
\hline \multirow[t]{2}{*}{$\ln$ (initial GDP per capita) } & -0.007 & -0.176 & -0.009 & -0.114 & -0.009 & -0.092 \\
\hline & $(2.04)$ & (6.13) & (2.59) & (4.54) & $(2.81)$ & $(5.42)$ \\
\hline \multirow[t]{2}{*}{$\ln ($ gdi) } & 0.032 & 0.059 & 0.030 & 0.052 & 0.024 & 0.08 \\
\hline & $(4.34)$ & $(3.71)$ & (4.19) & $(5.82)$ & $(3.33)$ & (9.87) \\
\hline \multirow[t]{2}{*}{$\ln (1+\mathrm{fdi})$} & & & 0.479 & 1.147 & 0.538 & 1.502 \\
\hline & & & $(2.65)$ & $(4.65)$ & $(2.53)$ & $(4.43)$ \\
\hline \multirow[t]{2}{*}{$\ln (1+\mathrm{fdi})^{2}$} & & & 0.375 & $-9.743^{\dagger}$ & -7.759 & $-13.296^{\dagger}$ \\
\hline & & & $(0.16)$ & $(3.34)$ & $(1.64)$ & $(2.84)$ \\
\hline \multirow[t]{2}{*}{ Human capital } & & & & & -0.0002 & $0.016^{\dagger}$ \\
\hline & & & & & $(0.17)$ & $(3.06)$ \\
\hline \multirow[t]{2}{*}{ Effect of aid at median } & 0.144 & 0.105 & 0.106 & $0.313^{\dagger}$ & 0.091 & -0.053 \\
\hline & (1.93) & $(0.45)$ & $(1.51)$ & $(2.43)$ & (1.01) & $(0.57)$ \\
\hline Degrees of freedom & 253 & 201 & 250 & 198 & 195 & 154 \\
\hline$\hat{\sigma}_{\varepsilon} \times 100$ & 2.83 & 2.57 & 2.78 & 2.34 & 2.48 & 2.02 \\
\hline Sargan test ${ }^{a}$ & & 0.38 & & 0.33 & & 0.45 \\
\hline
\end{tabular}

Heteroskedasticity-consistent $t$-values in parenthesis. Time dummies are included in all regressions. ${ }^{\dagger}$ The parameter is not significant at the $10 \%$ level in a one-step GMM estimation. ${ }^{a}$ The $p$-value of Sargan's test for overidentifying restrictions. Institutional quality and dummies for Sub-Saharan Africa and East Asia are included in the OLS regressions. 
Table 5

Investment regressions

\begin{tabular}{|c|c|c|c|c|}
\hline \multirow{4}{*}{$\begin{array}{l}\text { Dependent variable } \\
\text { Sample } \\
\text { Estimation method } \\
\text { Regression }\end{array}$} & \multicolumn{4}{|c|}{ The share of gross domestic investment in GDP } \\
\hline & \multicolumn{2}{|c|}{56 countries } & \multicolumn{2}{|c|}{45 countries } \\
\hline & $\mathrm{FE}$ & GMM & FE & GMM \\
\hline & 5.1 & 5.2 & 5.3 & 5.4 \\
\hline \multirow{2}{*}{$\overline{\text { Aid }}$} & 0.714 & 1.119 & 0.554 & 0.977 \\
\hline & $(3.77)$ & $(4.02)$ & $(2.77)$ & $(7.98)$ \\
\hline \multirow[t]{2}{*}{$\operatorname{Aid}^{2}$} & -0.808 & $-1.841^{\dagger}$ & -1.862 & -3.011 \\
\hline & $(1.62)$ & $(3.33)$ & $(1.91)$ & $(4.49)$ \\
\hline \multirow[t]{2}{*}{$\Delta$ Aid } & -0.398 & -1.295 & -0.309 & -0.731 \\
\hline & $(2.56)$ & $(8.29)$ & $(2.00)$ & $(13.1)$ \\
\hline \multirow[t]{2}{*}{$\Delta \mathrm{Aid}^{2}$} & 0.675 & 2.378 & 3.70 & $3.641^{\dagger}$ \\
\hline & $(2.10)$ & (8.73) & (3.06) & (6.32) \\
\hline \multirow[t]{2}{*}{ Fdi } & 0.185 & -1.696 & 0.111 & $-0.940^{\dagger}$ \\
\hline & $(0.37)$ & $(4.25)$ & $(0.34)$ & $(3.26)$ \\
\hline \multirow[t]{2}{*}{$\mathrm{Fdi}^{2}$} & 0.968 & 18.515 & 7.586 & $12.388^{\dagger}$ \\
\hline & $(0.16)$ & $(3.96)$ & (1.49) & (2.64) \\
\hline \multirow[t]{2}{*}{ Inflation } & 0.015 & $0.034^{\dagger}$ & -0.006 & $-0.025^{\dagger}$ \\
\hline & $(1.35)$ & $(2.38)$ & $(0.79)$ & $(2.92)$ \\
\hline \multirow[t]{2}{*}{ Openness } & 0.012 & 0.02 & 0.025 & 0.024 \\
\hline & (1.19) & $(1.98)$ & $(3.07)$ & $(4.42)$ \\
\hline \multirow[t]{2}{*}{ Growth rate in GDP per capita } & 0.609 & 0.568 & 0.565 & 0.496 \\
\hline & (7.03) & $(6.67)$ & $(6.84)$ & $(4.79)$ \\
\hline \multirow[t]{2}{*}{$\ln$ (initial GDP per capita) } & 0.173 & 0.161 & 0.185 & 0.193 \\
\hline & $(9.17)$ & $(4.04)$ & $(12.25)$ & $(15.4)$ \\
\hline \multirow[t]{2}{*}{ Human capital } & & & -0.027 & -0.034 \\
\hline & & & $(2.46)$ & $(3.08)$ \\
\hline \multirow[t]{2}{*}{ Effect of aid at median } & 0.759 & 1.223 & 0.658 & 1.146 \\
\hline & $(3.55)$ & $(3.98)$ & $(2.83)$ & $(7.55)$ \\
\hline Degrees of freedom & 199 & 199 & 155 & 155 \\
\hline$\hat{\sigma}_{\varepsilon} \times 100$ & 3.77 & 4.04 & 2.99 & 2.63 \\
\hline Sargan test ${ }^{a}$ & & 0.38 & & 0.33 \\
\hline
\end{tabular}

The parameter is not significant at the 10\% level in a one-step GMM estimation. ${ }^{a}$ The $p$-value of Sargan's test for overidentifying restrictions. Heteroskedasticityconsistent $t$-values in parenthesis. Time dummies are included in all regressions. 


\section{CREDIT PAPERS}

98/1 Norman Gemmell and Mark McGillivray, "Aid and Tax Instability and the Government Budget Constraint in Developing Countries"

98/2 Susana Franco-Rodriguez, Mark McGillivray and Oliver Morrissey, "Aid and the Public Sector in Pakistan: Evidence with Endogenous Aid"

98/3 Norman Gemmell, Tim Lloyd and Marina Mathew, "Dynamic Sectoral Linkages and Structural Change in a Developing Economy"

98/4 Andrew McKay, Oliver Morrissey and Charlotte Vaillant, "Aggregate Export and Food Crop Supply Response in Tanzania"

98/5 Louise Grenier, Andrew McKay and Oliver Morrissey, "Determinants of Exports and Investment of Manufacturing Firms in Tanzania"

98/6 P.J. Lloyd, "A Generalisation of the Stolper-Samuelson Theorem with Diversified Households: A Tale of Two Matrices"

98/7 P.J. Lloyd, "Globalisation, International Factor Movements and Market Adjustments"

98/8 Ramesh Durbarry, Norman Gemmell and David Greenaway, "New Evidence on the Impact of Foreign Aid on Economic Growth"

98/9 Michael Bleaney and David Greenaway, "External Disturbances and Macroeconomic Performance in Sub-Saharan Africa"

98/10 Tim Lloyd, Mark McGillivray, Oliver Morrissey and Robert Osei, "Investigating the Relationship Between Aid and Trade Flows"

98/11 A.K.M. Azhar, R.J.R. Eliott and C.R. Milner, "Analysing Changes in Trade Patterns: A New Geometric Approach"

98/12 Oliver Morrissey and Nicodemus Rudaheranwa, "Ugandan Trade Policy and Export Performance in the 1990s"

98/13 Chris Milner, Oliver Morrissey and Nicodemus Rudaheranwa, "Protection, Trade Policy and Transport Costs: Effective Taxation of Ugandan Exporters"

99/1 Ewen Cummins, "Hey and Orme go to Gara Godo: Household Risk Preferences"

99/2 Louise Grenier, Andrew McKay and Oliver Morrissey, "Competition and Business Confidence in Manufacturing Enterprises in Tanzania"

99/3 Robert Lensink and Oliver Morrissey, "Uncertainty of Aid Inflows and the Aid-Growth Relationship"

99/4 Michael Bleaney and David Fielding, "Exchange Rate Regimes, Inflation and Output Volatility in Developing Countries"

99/5 Indraneel Dasgupta, “Women's Employment, Intra-Household Bargaining and Distribution: A Two-Sector Analysis"

99/6 Robert Lensink and Howard White, "Is there an Aid Laffer Curve?"

99/7 David Fielding, "Income Inequality and Economic Development: A Structural Model"

99/8 Christophe Muller, "The Spatial Association of Price Indices and Living Standards"

99/9 Christophe Muller, "The Measurement of Poverty with Geographical and Intertemporal Price Dispersion" 
99/10 Henrik Hansen and Finn Tarp, "Aid Effectiveness Disputed"

99/11 Christophe Muller, "Censored Quantile Regressions of Poverty in Rwands"

99/12 Michael Bleaney, Paul Mizen and Lesedi Senatla, "Portfolio Capital Flows to Emerging Markets"

99/13 Christophe Muller, "The Relative Prevalence of Diseases in a Population if Ill Persons"

00/1 Robert Lensink, "Does Financial Development Mitigate Negative Effects of Policy Uncertainty on Economic Growth?"

00/2 Oliver Morrissey, "Investment and Competition Policy in Developing Countries: Implications of and for the WTO"

00/3 Jo-Ann Crawford and Sam Laird, "Regional Trade Agreements and the WTO"

00/4 Sam Laird, "Multilateral Market Access Negotiations in Goods and Services"

00/5 Sam Laird, "The WTO Agenda and the Developing Countries"

00/6 Josaphat P. Kweka and Oliver Morrissey, "Government Spending and Economic Growth in Tanzania, 1965-1996"

00/7 Henrik Hansen and Fin Tarp, "Aid and Growth Regressions" 


\section{DEPARTMENT OF ECONOMICS DISCUSSION PAPERS}

In addition to the CREDIT series of research papers the Department of Economics produces a discussion paper series dealing with more general aspects of economics. Below is a list of recent titles published in this series.

98/1 David Fielding, "Social and Economic Determinants of English Voter Choice in the 1997 General Election"

98/2 Darrin L. Baines, Nicola Cooper and David K. Whynes, "General Practitioners' Views on Current Changes in the UK Health Service"

98/3 Prasanta K. Pattanaik and Yongsheng Xu, "On Ranking Opportunity Sets in Economic Environments"

98/4 David Fielding and Paul Mizen, "Panel Data Evidence on the Relationship Between Relative Price Variability and Inflation in Europe"

98/5 John Creedy and Norman Gemmell, "The Built-In Flexibility of Taxation: Some Basic Analytics"

98/6 Walter Bossert, "Opportunity Sets and the Measurement of Information"

98/7 Walter Bossert and Hans Peters, "Multi-Attribute Decision-Making in Individual and Social Choice"

98/8 Walter Bossert and Hans Peters, "Minimax Regret and Efficient Bargaining under Uncertainty"

98/9 Michael F. Bleaney and Stephen J. Leybourne, "Real Exchange Rate Dynamics under the Current Float: A Re-Examination"

98/10 Norman Gemmell, Oliver Morrissey and Abuzer Pinar, "Taxation, Fiscal Illusion and the Demand for Government Expenditures in the UK: A TimeSeries Analysis"

98/11 Matt Ayres, "Extensive Games of Imperfect Recall and Mind Perfection"

98/12 Walter Bossert, Prasanta K. Pattanaik and Yongsheng Xu, "Choice Under Complete Uncertainty: Axiomatic Characterizations of Some Decision Rules"

98/13 T. A. Lloyd, C. W. Morgan and A. J. Rayner, "Policy Intervention and Supply Response: the Potato Marketing Board in Retrospect"

98/14 Richard Kneller, Michael Bleaney and Norman Gemmell, "Growth, Public Policy and the Government Budget Constraint: Evidence from OECD Countries"

98/15 Charles Blackorby, Walter Bossert and David Donaldson, "The Value of Limited Altruism"

98/16 Steven J. Humphrey, "The Common Consequence Effect: Testing a Unified Explanation of Recent Mixed Evidence"

98/17 Steven J. Humphrey, "Non-Transitive Choice: Event-Splitting Effects or Framing Effects"

98/18 Richard Disney and Amanda Gosling, "Does It Pay to Work in the Public Sector?"

98/19 Norman Gemmell, Oliver Morrissey and Abuzer Pinar, "Fiscal Illusion and the Demand for Local Government Expenditures in England and Wales"

98/20 Richard Disney, "Crises in Public Pension Programmes in OECD: What Are the Reform Options?"

98/21 Gwendolyn C. Morrison, “The Endowment Effect and Expected Utility” 
98/22 G.C. Morrisson, A. Neilson and M. Malek, "Improving the Sensitivity of the Time Trade-Off Method: Results of an Experiment Using Chained TTO Questions"

99/1 Indraneel Dasgupta, "Stochastic Production and the Law of Supply"

99/2 Walter Bossert, "Intersection Quasi-Orderings: An Alternative Proof"

99/3 Charles Blackorby, Walter Bossert and David Donaldson, "Rationalizable Variable-Population Choice Functions"

99/4 Charles Blackorby, Walter Bossert and David Donaldson, "Functional Equations and Population Ethics"

99/5 Christophe Muller, “A Global Concavity Condition for Decisions with Several Constraints"

99/6 Christophe Muller, "A Separability Condition for the Decentralisation of Complex Behavioural Models"

99/7 Zhihao Yu, "Environmental Protection and Free Trade: Indirect Competition for Political Influence"

99/8 Zhihao Yu, "A Model of Substitution of Non-Tariff Barriers for Tariffs"

99/9 Steven J. Humphrey, "Testing a Prescription for the Reduction of NonTransitive Choices"

99/10 Richard Disney, Andrew Henley and Gary Stears, "Housing Costs, House Price Shocks and Savings Behaviour Among Older Households in Britain"

99/11 Yongsheng Xu, "Non-Discrimination and the Pareto Principle"

99/12 Yongsheng Xu, "On Ranking Linear Budget Sets in Terms of Freedom of Choice"

99/13 Michael Bleaney, Stephen J. Leybourne and Paul Mizen, "Mean Reversion of Real Exchange Rates in High-Inflation Countries"

99/14 Chris Milner, Paul Mizen and Eric Pentecost, “A Cross-Country Panel Analysis of Currency Substitution and Trade"

99/15 Steven J. Humphrey, "Are Event-splitting Effects Actually Boundary Effects?"

99/16 Taradas Bandyopadhyay, Indraneel Dasgupta and Prasanta K. Pattanaik, "On the Equivalence of Some Properties of Stochastic Demand Functions"

99/17 Indraneel Dasgupta, Subodh Kumar and Prasanta K. Pattanaik, "Consistent Choice and Falsifiability of the Maximization Hypothesis"

99/18 David Fielding and Paul Mizen, "Relative Price Variability and Inflation in Europe"

99/19 Emmanuel Petrakis and Joanna Poyago-Theotoky, "Technology Policy in an Oligopoly with Spillovers and Pollution"

99/20 Indraneel Dasgupta, "Wage Subsidy, Cash Transfer and Individual Welfare in a Cournot Model of the Household"

99/21 Walter Bossert and Hans Peters, "Efficient Solutions to Bargaining Problems with Uncertain Disagreement Points"

99/22 Yongsheng Xu, "Measuring the Standard of Living - An Axiomatic Approach"

99/23 Yongsheng Xu, "No-Envy and Equality of Economic Opportunity" 
99/24 M. Conyon, S. Girma, S. Thompson and P. Wright, "The Impact of Mergers and Acquisitions on Profits and Employee Remuneration in the United Kingdom"

99/25 Robert Breunig and Indraneel Dasgupta, "Towards an Explanation of the Cash-Out Puzzle in the US Food Stamps Program"

99/26 John Creedy and Norman Gemmell, "The Built-In Flexibility of Consumption Taxes"

99/27 Richard Disney, "Declining Public Pensions in an Era of Demographic Ageing: Will Private Provision Fill the Gap?"

99/28 Indraneel Dasgupta, "Welfare Analysis in a Cournot Game with a Public Good"

99/29 Taradas Bandyopadhyay, Indraneel Dasgupta and Prasanta K. Pattanaik, "A Stochastic Generalization of the Revealed Preference Approach to the Theory of Consumers' Behavior"

99/30 Charles Blackorby, WalterBossert and David Donaldson, "Utilitarianism and the Theory of Justice"

99/31 Mariam Camarero and Javier Ordóñez, "Who is Ruling Europe? Empirical Evidence on the German Dominance Hypothesis"

99/32 Christophe Muller, "The Watts' Poverty Index with Explicit Price Variability"

99/33 Paul Newbold, Tony Rayner, Christine Ennew and Emanuela Marrocu, "Testing Seasonality and Efficiency in Commodity Futures Markets"

99/34 Paul Newbold, Tony Rayner, Christine Ennew and Emanuela Marrocu, "Futures Markets Efficiency: Evidence from Unevenly Spaced Contracts"

99/35 Ciaran O'Neill and Zoe Phillips, "An Application of the Hedonic Pricing Technique to Cigarettes in the United Kingdom"

99/36 Christophe Muller, "The Properties of the Watts' Poverty Index Under Lognormality"

99/37 Tae-Hwan Kim, Stephen J. Leybourne and Paul Newbold, "Spurious Rejections by Perron Tests in the Presence of a Misplaced or Second Break Under the Null"

00/1 Tae-Hwan Kim and Christophe Muller, "Two-Stage Quantile Regression"

00/2 Spiros Bougheas, Panicos O. Demetrides and Edgar L.W. Morgenroth, "International Aspects of Public Infrastructure Investment"

00/3 Michael Bleaney, "Inflation as Taxation: Theory and Evidence" 


\section{Members of the Centre}

\section{Director}

Oliver Morrissey - aid policy, trade and agriculture

\section{Research Fellows (Internal)}

Adam Blake - CGE models of low-income countries

Mike Bleaney - growth, international macroeconomics

Indraneel Dasgupta - development theory

Norman Gemmell - growth and public sector issues

Ken Ingersent - agricultural trade

Tim Lloyd - agricultural commodity markets

Andrew McKay - poverty, peasant households, agriculture

Chris Milner - trade and development

Wyn Morgan - futures markets, commodity markets

Christophe Muller - poverty, household panel econometrics

Tony Rayner - agricultural policy and trade

\section{Research Fellows (External)}

V.N. Balasubramanyam (University of Lancaster) - foreign direct investment and multinationals

David Fielding (Leicester University) - investment, monetary and fiscal policy

Göte Hansson (Lund University) - trade, Ethiopian development

Robert Lensink (University of Groningen) - aid, investment, macroeconomics

Scott McDonald (Sheffield University) - CGE modelling, agriculture

Mark McGillivray (RMIT University) - aid allocation, human development

Jay Menon $(A D B$, Manila) - trade and exchange rates

Doug Nelson (Tulane University) - political economy of trade

David Sapsford (University of Lancaster) - commodity prices

Finn Tarp (University of Copenhagen) - aid, CGE modelling

Howard White (IDS) - aid, poverty 